УДК 343.8

DOI https://doi.org/10.32849/2663-5313/2020.9.41

Дмитро Сирота,

канд. юрид. наук,

дочент кафедри галузевих юридичних наук

Кременчуцького начіонального університету імені Михайла Остроградського

Тетяна Слободяник,

канд. юрид. наук,

дочент кафедри галузевих юридччних наук

Кременчуцького національного університету імені Михайла Остроградського

\title{
ФУНКЦІЯ ДОСУДОВОГО РОЗСЛІДУВАННЯ ПРОКУРАТУРИ
}

Ефективність захисту прав, свобод, інтересів людини та суспільства загалом від кримінальних правопорушень залежить від визначення правоохоронних функиій, їх чіткого розподілу між компетентними органами та професійного виконання. Виконання державним правоохоронним органом функиії, яка не передбачена для нього Основним Законом, виключає існування правової системи. Очевидно, що кримінально-прочесуальна функиія досудового розслідування має виконуватись органами з однойменною назвою. Проте норми чинного Кримінального процесуального кодексу покладають на прокурорів обов'язок здійснення досудового розслідування у кримінальному провадженні. Водночас прокуратура наділена іншими функціями, вичерпний перелік яких передбачено статтею 131-1 Конституиії України [1]. Вважаємо, що такий стан справ унеможливлює встановлення в країні правопорядку.

У статті досліджується питання діяльності прокуратури в часи незалежності Украйни, зокрема виконання прокурорами кримінально-процесуальних функцій. Встановлено, що з дати ухвалення Конституиї України і по теперішній час прокуратура виконує функиію, не передбачену Основним Законом, - функиію досудового розслідування. Реформування прокуратури та правоохоронної системи загалом відбувалося та відбувається формально. Політичне керівниитво держави усіляко намагалось залишити за прокурорами право - обов'язок розслідувати кримінальні провадження. У 2012 рочі набрав чинності новий Кримінальний прочесуальний Кодекс України. Серед чисельних новацій у правилах кримінального процесу позиція законодавия щодо антиконституиійного закріплення за прокуратурою функиї досудового розслідування залишилась незмінною. Відтак ми доходимо висновку, що норми чинного Кримінального процесуального Кодексу України всупереч Конституиії покладають на органи прокуратури функиію досудового розслідування у кримінальних провадженнях.

Ключові слова. Конституція України, Кримінальний процесуальний кодекс України, функції прокуратури, функція досудового розслідування, прокурор, слідчий.

Постановка проблеми. В Україні триває реформування системи кримінальної юстиції. У цій царині вже багато зроблено: змінено порядок кримінального провадження; встановлено нові правові засади організації та діяльності судів, органів досудового розслідування та адвокатури. Також досить активно у правозастосуванні впроваджуються європейські стандарти захисту прав учасників кримінального провадження. Дозволимо собі припустити, що із прийняттям нового Кримінального процесуального кодексу України (далі - КПК) зменшилася кількість свавільних обшуків і затримань, випадків фізичного та психологічного примусу з метою отримання доказів, незаконного кримінального переслідування загалом. Певні здобутки можна перераховувати й далі, адже якість проведення досудового розслідування перебуває на вкрай низькому рівні. На нашу думку, однією з причин цього $€$ формальний підхід до реформування інституту прокуратури, зокрема функцій прокурора у кримінальному процесі.

За часів незалежності положення Конституції України щодо функцій прокуратури неодноразово змінювались. Хоча жодна їх редакція не покладала на прокуратуру функцію досудового розслідування, прокуратура iï здійснювала і має здійснювати зараз. Відповідно до чинної ст. 131-1 Конституції України прокуратура здійснює: 1) підтримання публічного обвинувачення в суді; 2) організацію і процесуальне керівництво досудовим розслідуванням, вирішення відповідно до закону інших 
питань під час кримінального провадження, нагляд за негласними та іншими слідчими i розшуковими діями органів правопорядку; 3) представництво інтересів держави в суді у виключних випадках і в порядку, що визначені законом [1]. У ч. 3 ст. 2 Закону України «Про прокуратуру» № 1697-VII від 14.10.2014 року вказано, що на прокуратуру не можуть покладатися функції, не передбачені Конституцією України [2]. Водночас КПК встановлює кримінальнопроцесуальні права-обов'язки прокурорів для реалізації покладених на них функцій. Вважаємо, що засади кримінального провадження та інші норми КПК покладають на прокурорів обов'язок здійснювати досудове розслідування у кримінальних провадженнях. Фактично прокурор перетворився на слідчого, а слідчий на його помічника. Отже, проблему вбачаємо у тому, що на прокурорів всупереч нормам Основного закону покладено функцію досудового розслідування.

Аналіз останніх досліджень і публікацій. Функції, права та обов'язки прокурора у кримінальному процесі були предметом дослідження таких учених, як Ю.П. Аленін, В.М. Бабкова, А.М. Баксалова, O.М. Бандурка, І.В. Гловюк, В.В. Долежан, О.В. Капліна, П.М. Каркач, М.В. Косюта, O.M. Ларін, А.О. Ломакін, В.І. Малюга, М.I. Мичко, В.П. Півненко, І.В. Рогатюк, М.В. Руденко, В.М. Савицький, В.А. Стремовський, О.Ю. Татаров, О.М. Толочко, М.С. Трубін, В.М. Юрчишин, Н.I. Щегель та багатьох інших. Однак здебільшого дослідження присвячувались змісту та співвідношенню понять «нагляд» та «процесуальне керівництво», а також порядку взаємодії слідчого та прокурора. Дослідженню обов'язків прокурора щодо здійснення досудового розслідування у кримінальному провадженні за новим КПК, на нашу думку, приділено недостатньо уваги.

Метою статті є дослідження процесу реформування кримінально-процесуальної діяльності прокурора та формування системи досудового розслідування в аспекті виконання прокуратурою функції досудового розслідування; висвітлення питання виконання прокуратурою функції досудового розслідування, яка не передбачена Конституцією України.

Виклад основного матеріалу. За часів незалежності влада вдавала, що намагається впорядкувати питання кримінально-процесуальної діяльності прокуратури як державного органу та прокурора як суб'єкта кримінального провадження. Йдеться про маніпуляції законодавця з суб'єктом вико- нання функції досудового розслідування, яку виконувала та має продовжувати виконувати прокуратура України. 3 одного боку, ми спостерігали дуже кволий процес позбавлення прокуратури функції досудового розслідування, а з іншого - бачимо як прокурорам підступно нав'язали цю функцію. Напевно самі прокурори повністю не усвідомлюють, що зараз вони мають розслідувати кримінальні провадження замість слідчих.

Відповідно до висновку Парламентської асамблеї Ради Свропи від 26 вересня 1995 р. № 190 (1995) щодо заявки України на вступ до Ради Європи необхідність ліквідації прокурорської функції досудового слідства обгрунтовується унеможливленням поєднання в одному органі слідчих повноважень і здійснення нагляду за їх реалізацією, бо такий нагляд не може бути об'єктивним [3]. Як зазначалось вище, положення Конституції України, якими визначалися функції прокуратури, з 1996 року по сьогоднішній день змінювались кілька разів. Однак як первісний текст Основного Закону, так i його подальші редакції не покладали на прокуратуру функцію здійснення досудового розслідування у кримінальних справах. Водночас Закон України «Про прокуратуру» № 1789-XII від 05.11.1991 року та Кримінально-процесуальний кодекс України № 1001-05 від 28.12.1960 року передбачали в структурі органів прокуратури посади слідчих та надавали повноваження розслідувати певні види злочинів [4; 5]. Очевидно, що норми цих нормативно-правових актів не відповідали ст. 121 Основного Закону (ред. 28.06 .1996 р.) Щоб легітимізувати слідчу діяльність прокуратури, у Конституції було передбачено суперечливий пункт 9 розділу XV «Перехідні положення», відповідно до якого прокуратура продовжує виконувати відповідно до чинних законів функцію нагляду за додержанням і застосуванням законів та функцію попереднього слідства до введення в дію законів, що регулюють діяльність державних органів щодо контролю за додержанням законів, та до сформування системи досудового слідства і введення в дію законів, що регулюють її функціонування [1]. Народні обранці, включаючи відповідне положення до перехідних положень, свідомо заплющили очі на ст. ст. 19, 121 Конституції. Сьогодні з упевненістю можна говорити, що цей пункт Конституції був одним із проявів небажання влади відходити від радянської системи державного контролю над суспільством. Влада тривалий час навіть не намагалася формувати систему досудового слідства та розробляти відповідну законодавчу базу. У 2016 році п. 9 викладено у новій редакції 
«Прокуратура продовжує виконувати відповідно до чинних законів функцію досудового розслідування до початку функціонування органів, яким законом будуть передані відповідні функції...» [6].

У 2006 році Конституції виповнилося вже 10 років. До формування системи досудового слідства справа так і не дійшла. Натомість з 01.01.2006 року Законом № 2222-IV від 08.12.2004 року до ст. 122 Конституції України включено п. 5, яким прокурорів обтяжили додатковою функцією - нагляду за додержанням прав і свобод людини і громадянина, додержанням законів з цих питань органами виконавчої влади, органами місцевого самоврядування, іх посадовими і службовими особами [7]. Закон № 2222-IV визнано неконституційним згідно з Рішенням Конституційного Суду N 20-рп/2010 від 30.09.2010 у зв'язку з порушенням конституційної процедури його розгляду та прийняття.

У 2008 році предметом конституційного розгляду стала справа «про повноваження прокуратури відповідно до пункту 9 розділу XV «Перехідні положення»Конституції України» за конституційним поданням 46 народних депутатів. Конституційний суд 10 вересня 2008 року визнав такими, що відповідають Конституції України (є конституційними), положення статті 17 Закону України «Про прокуратуру» від 5 листопада 1991 року N 1789-XII на час дії пункту 9 розділу XV «Перехідні положення» Конституції України щодо продовження виконання прокуратурою відповідно до чинних законів функції попереднього слідства до сформування системи досудового слідства і введення в дію законів, що регулюють її функціонування (справа № 1-29/2008) [8]. Важливим меседжем керівництву держави за результатами розгляду справи мала стати окрема думка судді Марії Андріївни Маркуш. Суддя висловила думку, що повноваження прокурорів повинні відповідати функціям прокуратури, закріпленим у статті 121 Конституції України, в іншому випадку ці повноваження виходять за конституційні межі функцій цього органу, що суперечить положенням частини другої статті 19, статті 121, пункту 1 розділу XV «Перехідні положення» Конституції України. Оскільки норми Конституції України $є$ нормами прямої дії, то Закон повинен відповідати їй (стаття 8 Конституції України). Оспорювані положення Закону передбачають додаткові підстави обмеження прав і свобод людини і громадянина [9].

Утім іншого рішення Конституційного суду годі було й очікувати. У разі визнання неконституційними положень ст. 17 Закону України «Про прокуратуру» від 5 листопада
1991 року, злочини підслідні слідчим прокуратури розслідувати стало б нікому. Важко уявити навіть наслідки такого рішення Питання в тому, що Рішення Конституційного суду та окрема думка судді Маркуш М.А. мали б стати додатковим поштовхом для активізації подальших дій влади щодо створення відповідних слідчих органів та приведення діяльності прокуратури у відповідність до вимог Основного Закону. Конституційний Суд України у Рішенні звернув увагу Верховної Ради України на необхідності законодавчої реалізації положень пункту 9 розділу XV «Перехідні положення» Конституції України (пункт 3 резолютивної частини Рішення), однак розв'язання цього питання знову затягнулося на роки.

13 квітня 2012 року Верховна Рада України ухвалила новий Кримінальний процесуальний кодекс України, який набрав чинності 19 листопада 2012 року. Положення нового кодексу щодо порядку здійснення кримінального провадження можна назвати революційними та тільки не стосовно кримінально-процесуальної діяльності прокуратури. На відміну від Кримінально-процесуального кодексу України № 1001-05 від 28.12.1960 року положення нового кодексу вже не передбачали слідчих прокуратури в переліку органів досудового розслідування. За новим КПК до системи органів досудового розслідування включено органи державного бюро розслідувань, а пізніше підрозділ детективів, підрозділ внутрішнього контролю Національного антикорупційного бюро України, створення яких ще планувалось. Ч. 4 та 5 ст. 216 КПК уповноважували вказані органи здійснювати досудове розслідування у кримінальних правопорушеннях, вчинених високопосадовцями, суддями та правоохоронцями, а також військові злочини [10]. Процес створення цих органів гальмувався як і раніше, оскільки залишався діючим п. 9 розділу XV "Перехідних положень" Конституції України». Та навіть після створення ДБР та НАБУ прокуратура продовжує здійснювати досудове розслідування у кримінальних провадженнях.

Відповідно до положень п. 1 Розділу X «Прикінцеві положення» КПК (в ред. станом на 18.05.2020 року) положення частини четвертої статті 216 цього Кодексу вводяться в дію з дня початку діяльності Державного бюро розслідувань України, але не пізніше п'яти років 3 дня набрання чинності цим Кодексом (20 листопада 2017 року); положення частини п'ятої статті 216 цього Кодексу вводиться в дію 3 дня початку діяльності Національного антикорупційного бюро України, але не пізніше трьох років з дня 
набрання чинності цим Кодексом (20 листопада 2015 року). П.1 розділу ХІ «Перехідних положень» КПК (в ред. станом на 18.05.2020 року) встановлено: 1) до дня введення в дію положень частини четвертої статті 216 цього Кодексу повноваження щодо досудового розслідування здійснюють слідчі органів прокуратури, які користуються повноваженнями слідчих, визначеними цим Кодексом щодо злочинів, передбачених частиною четвертою статті 216 цього Кодексу. У разі неможливості закінчити досудове розслідування у таких провадженнях до спливу дворічного строку або за наявності інших передбачених законом підстав питання про доручення його здійснення іншим органам досудового розслідування вирішується в установленому цим Кодексом порядку. Передача кримінальних проваджень до Державного бюро розслідувань здійснюється 3 урахуванням особливостей, визначених Законом України «Про Державне бюро розслідувань»; 2) до дня введення в дію частини п'ятої статті 216 цього Кодексу повноваження щодо досудового розслідування передбачених нею злочинів здійснюють слідчі органів прокуратури, які користуються повноваженнями слідчих, визначеними цим Кодексом. Після введення в дію частини п'ятої статті 216 цього Кодексу розпочаті слідчими органів прокуратури кримінальні провадження продовжують здійснюватися слідчими органів прокуратури, які користуються повноваженнями слідчих, визначеними цим Кодексом, до закінчення досудового розслідування, але не пізніше дня початку діяльності Офісу Генерального прокурора, обласних прокуратур [10].

Очевидно, що наведені положення КПК не відповідають принципу правової визначеності. Дата остаточного вивільнення прокурорів від функції досудового розслідування фактично не визначена і пов'язана з настанням певної події, днем початку діяльності відповідно Офісу Генерального прокурора, обласних прокуратур. Закон № 113-IX від 19.09.2019 «Про внесення змін до деяких законодавчих актів України щодо першочергових заходів із реформи органів прокуратури» встановлює, що день початку роботи Офісу Генерального прокурора, обласних прокуратур, окружних прокуратур визначається рішеннями Генерального прокурора стосовно Офісу Генерального прокурора, усіх обласних прокуратур, усіх окружних прокуратур. Вказані рішення публікуються у газеті «Голос України» [11]. Офіс Генерального прокурора почав працювати 2 січня 2020 року. Обласні прокуратури до цього часу ще не сформовані.
В аспекті досліджуваного питання припустимо, що закон все ж визначає кінцевий строк здійснення прокурорами досудового розслідування кримінальних проваджень. Однак законодавець таки «нагородив» прокурорів функцією досудового розслідування.

Так, у новий КПК частково було перенесено п. 5 ч. 1 ст. 227 КПК України 1960 року, відповідно до якого прокурор, здійснюючи нагляд за виконанням законів органами дізнання і досудового слідства, бере участь у провадженні дізнання і досудового слідства і в необхідних випадках особисто провадить окремі слідчі дії або розслідування в повному обсязі по будь-якій справі. Відповідно до п. 4 ч. 2 ст. 36 чинного КПК прокурор, здійснюючи нагляд за додержанням законів під час проведення досудового розслідування у формі процесуального керівництва досудовим розслідуванням, серед іншого уповноважений в необхідних випадках особисто проводити слідчі (розшукові) та процесуальні дії в порядку, визначеному цим Кодексом [10]. Хоча у чинному КПК і не передбачено повноваження прокурора саме проводити розслідування в повному обсязі по будь-якій справі, проте інші норми КПК в своїй сукупності дають підстави вважати, що прокурор не тільки має право розслідувати кримінальне провадження, а й зобов'язаний це робити.

Насамперед обов'язок прокурора здійснювати досудове розслідування вбачається із змісту засад кримінального провадження. Відповідно до ч. 2 ст. 9 КПК (засада законності) прокурор, керівник органу досудового розслідування, слідчий зобов'язані всебічно, повно і неупереджено дослідити обставини кримінального провадження, виявити як ті обставини, що викривають, так і ті, що виправдовують підозрюваного, обвинуваченого, а також обставини, що пом'якшують чи обтяжують його покарання, надати їм належну правову оцінку та забезпечити прийняття законних i неупереджених процесуальних рішень; відповідно до ч. 4 ст. 22 КПК (засада змагальності сторін та свободи в поданні ними суду своїх доказів і у доведенні перед судом ї переконливості) повідомлення особі про підозру у вчиненні кримінального правопорушення, звернення з обвинувальним актом та підтримання державного обвинувачення у суді здійснюється прокурором; відповідно до ч. 1 ст. 25 КПК (засада публічності) прокурор, слідчий зобов'язані в межах своєї компетенції розпочати досудове розслідування в кожному випадку безпосереднього виявлення ознак кримінального правопорушення (за винятком випадків, коли кримінальне провадження може бути розпочате лише на 
підставі заяви потерпілого) або в разі надходження заяви (повідомлення) про вчинення кримінального правопорушення, а також вжити всіх передбачених законом заходів для встановлення події кримінального правопорушення та особи, яка його вчинила; відповідно до ч. 2 ст. 28 КПК (засада розумності строків) проведення досудового розслідування у розумні строки забезпечує прокуpop [10]. На нашу думку, наведені положення достатньою мірою свідчать про покладення на прокурора функції досудового розслідування.

Інші норми КПК надають прокурору повноту повноважень на проведення досудового розслідування. Так, прокурор уповноважений звертатися з клопотаннями до слідчого судді про застосування заходів забезпечення кримінального провадження та отриманням дозволу на проведення певних слідчих дій, збирати докази, закривати кримінальне провадження, звертатися до суду з обвинувальним актом тощо. Також прокурор має право проводити усі без винятку слідчі дії. Щодо проведення негласних слідчих розшукових дій, слід зазначити, що прокурор хоч і не має такого права, однак має право доручати їх проведення слідчому та оперативним підрозділам. Зрештою, відповідно до ч.ч. 2, 3 ст. 283 КПК прокурор зобов'язаний у найкоротший строк після повідомлення особі про підозру здійснити одну з таких дій: 1) закрити кримінальне провадження; 2) звернутися до суду з клопотанням про звільнення особи від кримінальної відповідальності; 3) звернутися до суду з обвинувальним актом, клопотанням про застосування примусових заходів медичного або виховного характеру. Відомості про закінчення досудового розслідування вносяться прокурором до Єдиного реєстру досудових розслідувань [10].

Ми погоджуємося 3 позицією М. Бортуна, який вказує, що прокурор не повинен виконувати функції слідчого, а лише здійснювати нагляд за розслідуванням кримінального провадження у формі процесуального керівництва. Це означає, що прокурор або визнає процесуальні дії слідчого законними і погоджується з ними, або не визнає і відхиляє клопотання слідчого, визначає обсяг доказів достатнім для повідомлення особі про підозру і встановлює подальший хід розслідування. Слідчий своєю чергою обирає тактичні прийоми розслідування злочинів i погоджує їх із прокурором. Таким чином, створюється певний тандем слідчого і прокурора, який повинен забезпечити розслідування кримінального провадження [12].

B.M. Юрчишин наголошує, що прокурори України позбавлені функції досудового розслідування, та обгрунтовує необхід- ність наділення прокурорів цією функцією. Однак, на нашу думку, навпаки, прокурор наділений достатніми повноваженнями для самостійного здійснення досудового розслідування. Навіть більше, відповідно до норм КПК України він зобов'язаний це робити, що свідчить про покладення на нього відповідної функції [13].

О. Геселев зазначає, шо за змістом відповідних статей нового КПК прокурор, здійснюючи нагляд за додержанням законів під час проведення досудового розслідування у формі процесуального керівництва досудовим розслідуванням, знаходиться вже «поруч і разом зі слідчим». Прокурор у такому разі безпосередньо керує діями органу досудового розслідування щодо проведення певних процесуальних або слідчих дій, бере активну участь у проведенні будь-яких процесуальних, слідчих дій або сам безпосередньо проводить їх Ми своєю чергою не заперечуємо проти участі прокурора в окремих процесуальних діях, однак це має бути не обов'язком прокурора, а його правом у виняткових випадках [14]

\section{Висновки}

3 дати прийняття Конституції України прокуратура виконувала і має продовжувати виконувати функцію досудового розслідування. Влада за часів незалежності ухвалювала неконституційні законодавчі норми, якими наділяла прокурорів повноваженням розслідувати кримінальні провадження. Не є винятком і новий КПК, відповідно до норм якого на прокуратуру покладено функцію досудового розслідування.

\section{Список використаних джерел:}

1. Конституція України: Закон України від 28.06.1996 № 254к/96-BP. URL http://zakon2.rada.gov.uaJaws/show/254к/96-вр (дата звернення 02.04.2020).

2. Пропрокуратуру:Закон України№ 1697-VII від 14.10.2014. URL: https://zakon.rada.gov.ua/ laws/show/1697-18 (дата звернення 02.04.2020).

3. Висновок № 190 (1995) Парламентської Асамблеї Ради Європи щодозаявки України на вступ до Ради Європи. URL: https://zakon.rada.gov.ua/ laws/show/994_590 (дата звернення 02.04.2020).

4. Пропрокуратуру:Закон України№ 1789-XII від 05.11.1991. URL: https://zakon.rada.gov.ua/ laws/show/1789-12 (дата звернення 07.04.2020).

5. Кримінально-процесуальний кодекс України № 1001-05 від 28.12.1960. URL: https://zakon.rada.gov.ua/laws/show/100105 (дата звернення 07.04.2020).

6. Про внесення змін до Конституції України (щодо правосуддя): Закон України № 1401-VIII від 02.06.2016. URL: https://zakon.rada.gov.ua/ laws/show/1401-19 (дата звернення 02.04.2020). 
7. Про внесення змін до Конституції України : Закон України № 2222-IV від 08.12.2004. URL: https://zakon.rada.gov.ua/laws/show/2222-15 (дата звернення 21.04.2020).

8. Рішення Конституційного суду України № 15-рп/2008 від 10.09.2008. URL: http://www.ccu.gov.ua/docs/535 (дата звернення 21.04.2020).

9. Окрема думка судді Маркуш М.А. стосовно Рішення КСУ №15-рп/2008. URL: http://www.ccu.gov.ua/docs/535 (дата звернення 21.04.2020).

10. Кримінальний процесуальний кодекс України № 4651-VI від 13.04.2012. URL: https://zakon.rada.gov.ua/laws/show/4651-17 (дата звернення 02.04.2020).

11. Про внесення змін до деяких законодавчих актів України щодо першочергових захо- дів із реформи органів прокуратури : Закон України № 113-IX від 19.09.2019. URL: https://zakon.rada.gov.ua/laws/show/113-20 (дата звернення 29.04.2020).

12. Бортун М. Взаємодія прокурора зі слідчим, слідчим суддею на стадії досудового розслідування. Вісник національної академї прокуратури України. 2013. № 4. С. 95-100.

13. Юрчишин B.М. Функції безпосередньої участі прокурора у розслідуванні кримінальних справ за новим КПК України: бути чи не бути? URL: http://www.nbuv.gov.ua/e-journals/ Chaau/2012-2/12yumcnb.pdf (дата звернення 02.04.2020).

14. Геселев О. Процесуальний статус та повноваження прокурора за новим Кримінальним процесуальним кодексом України. Слово начіональної школи суддів України. 2012. № 1. С. 78-92.

Dmytro Syrota, Tetiana Slobodianyk. A function of the pre-trial investigation of the prosecutor's office

The protection effectiveness of human rights, freedoms, interests and society as a whole from criminal offences depends on the definition of law enforcement functions, their clear distribution among the competent authorities and professional performance. The performance by a State law enforcement agency of a function not provided for in the Basic Law precludes the existence of a legal system. It is obvious that the criminal procedure function of pre-trial investigation should be performed by the bodies of the same name. However, the provisions of the current Criminal Procedure Code oblige prosecutors to carry out pre-trial investigations in criminal proceedings. At the same time, the prosecutor's office has other functions, an exhaustive list of which is provided by Article 131-1 of the Constitution of Ukraine [1]. We consider that this state of affairs makes it impossible to establish law and order in the country.

The article examines the activities of the Procurator's Office during the independence of Ukraine, in particular the performance by procurators of their functions in criminal procedure. It has been established that from the date of adoption of the Constitution of Ukraine until the present time, the Procurator's Office performs the function of pre-trial investigation, which is not provided for in the Basic Law. The reform of the prosecutor's office and the law en forcement system in general hastaken place and istaking place formally. The state's political leadership tried to leave the right to prosecutors - to investigate criminal proceedings. The new Criminal Procedure Code of Ukraine entered into force in 2012. Among the many innovations in the rules of criminal procedure, the legislator's position on the unconstitutional assignment of the pre-trial investigation function to the Prosecutor's Office remained unchanged. We conclude that the norms of the current Criminal Procedure Code of Ukraine, contrary to the Constitution, entrust the prosecutor's office with the function of pre-trial investigation in criminal proceedings.

Key words: The Constitution of Ukraine, The Criminal Procedure Code of Ukraine, functions of the prosecutor's office, function of pre-trial investigation, procurator, investigator. 